\title{
Pemberdayaan UMKM Rosela Asri Kelurahan Pacar Kembang Kecamatan Tambaksari Kota Surabaya
}

\author{
Triyonowati ${ }^{*}$, Titik Mildawati2 ${ }^{2}$ Ikhsan Budi Riharjo ${ }^{3}$, Khuzaini ${ }^{4}$ \\ 1,2,3,4Sekolah Tinggi Ilmu Ekonomi Indonesia(STIESIA)Surabaya \\ e-mail: triyonowati@stiesia.ac.id ${ }^{1},{\text { titikmildawati@stiesia.ac.id², }{ }^{2} \text { khsanbudirihario@stiesia.ac.id }}^{3}$, \\ khuzaini@stiesia.ac.id 4 \\ * Penulis Korespondensi: E-mail: triyonowati@stiesia.ac.id
}

\begin{abstract}
Rosela Asri Handicraft UMKM Group, which is located in Pacar Kembang Village, Tambaksari District, Surabaya City, is one of the MSMEs with a micro-scale business that has the potential to be developed. The handicrafts that are produced include flannel and cotton creations, recycled products, delivery boxes, bags and wallets. Generally, the problems faced so far in micro businesses are the management of business finances that are still mixed with family finances and product marketing. So far, financial administration management has not been implemented optimally so that how much income is received and business expenses cannot be clearly identified. Increasing product sales using technology will be the best solution to help market the products produced by Rosela Asri MSMEs. Marketing through social media will make it easier for MSMEs to develop appropriate marketing strategies and supported by good financial management, it is hoped that it can maintain current business continuity in the post-COVID-19 pandemic and new normal and in the future. Based on the existing problems, training and mentoring are needed on simple bookkeeping and good marketing strategies. so that it is useful for improving the welfare of micro entrepreneurs.
\end{abstract}

Keywords: training, mentoring, financial management, marketing strategy

\begin{abstract}
Abstrak
Kelompok UMKM Kerajinan Tangan Rosela Asri yang berada di Kelurahan Pacar Kembang, Kecamatan Tambaksari Kota Surabaya merupakan salah satu UMKM dengan skala usaha mikro memiliki potensi untuk dikembangkan. Kerajinan tangan yang diproduksi antara lain kreasi flannel dan katun, daur ulang, box hantaran, tas, dan dompet. Seperti pada umumnya usaha mikro, permasalahan yang dihadapi selama ini adalah pengelolaan keuangan usaha yang masih tercampur menjadi satu dengan keuangan keluarga dan pemasaran produk. Pengelolaan administrasi keuangan selama ini belum dapat dijalankan secara optimal sehingga berapa pendapatan yang diterima dan pengeluaran usaha belum dapat diidentifikasi dengan jelas. Peningkatkan penjualan produk dengan menggunakan teknologi akan menjadi solusi terbaik untuk membantu pemasaran produk yang dihasilkan UMKM Rosela Asri. Pemasaran melalui media sosial akan memudahkan UMKM untuk menyusun strategi pemasaran yang tepat dan didukung pengelolaan keuangan yang baik diharapkian dapat menjaga kelangsungan usaha saat ini pada masa pasca pandemi covid 19 dan new normal serta kedepannya. Berdasarkan permasalahan yang ada diperlukan pelatihan dan pendampingan tentang pembukuan sederhana dan strategi pemasaran yang baik. sehingga bermanfaat bagi peningkatan kesejahteraan hidup pengusaha mikro .
\end{abstract}

Kata Kunci : pelatihan, pendampingan, pengelolaan keuangan, strategi pemasaran

\section{PENDAHULUAN}

Usaha Mikro, Kecil, dan Menengah (UMKM) merupakan suatu usaha perdagangan yang dikelola oleh perorangan atau badan usaha yang termasuk kriteria usaha dalam lingkup kecil atau mikro. UMKM ini telah diatur dalam peraturan Undang-Undang Nomor 20 Tahun 2008. Adapun pengertiannya adalah sebagai berikut; Usaha Mikro merupakan 
usaha produktif milik badan usaha atau perorangan dengan maksimal asset yang yang didapatkan untuk usaha tersebut adalah Rp. 50 juta sedangkan untuk maksimal omset sebesar Rp 300 juta rupiah, Usaha Kecil merupakan usaha ekonomi produktif yang berdiri sendiri, dilakukan oleh badan usaha atau perseorangan yang bukan anak atau cabang perusahaan yang dimiliki dengan kriteria asset usaha kecil ini berkisar dari Rp 50 juta - Rp 500 juta, sedangkan kriteria omset berkisar dari Rp 300 juta sampai Rp 2,5 miliar rupiah, sedangkan Usaha Menengah adalah usaha ekonomi produktif yang berdiri sendiri, dilakukan oleh perseorangan atau badan usaha yang bukan cabang atau anak perusahaan yang dimiliki atau menjadi bagian baik langsung maupun tidak langsung, dengan usaha besar atau kecil dengan jumal kekayaan bersih atau hasil penjualan tahunan dengan kriteria asset Rp 500 juta-Rp 10 miliar serta kriteria omset Rp 2,5 miliar sampai Rp 50 Miliar.

Dalam kegiatannya, UMKM dapat membantu perekonomian Indonesia, karena melalui UMKM akan membentuk lapangan kerja baru, memberi kontribusi terhadap pertumbuhan dan peningkatan kesejahteraan serta meningkatkan devisa negara dengan melalui pajak badan usaha. UMKM mempunyai potensi yang masih dapat dikembangkan, baik dalam produktivitas maupun daya saing. Keberadaan UMKM dapat berfungsi untuk menciptakan teknologi, produk, dan jasa baru yang dapat menciptakan perubahan dan kompetisi pada Pasar. Selain itu UMKM juga sangat bermanfaat bagi pelaku usahanya sendiri yang mana ia dapat meningkatkan kesejahteraan hidupnya. Dalam prosesnya, ada beberapa UMKM yang dapat berkembang dan kemudian menjadi sukses, namun tak sedikit yang mengalami kegagalan bahkan tak beroperasi. Kesuksesan UMKM dipengaruhi oleh banyak faktor diantaranya adanya pemasaran, teknologi serta modal. Di era sekarang, kehidupan manusia hampir tidak bisa dipisahkan dari aktivitas online atau internet.

Hampir semua kalangan dan semua profesi membutuhkan akses ke internet untuk memudahkan aktifitas mereka termasuk juga buat pebisnis. Pebisnis membutuhkan akses internet atau online untuk menjaga pangsa pasar mereka bahkan untuk menambah target pasar. Tentu, aktifitas online juga bisa dijadikan strategi pemasaran tertentu untuk mendapatkan pelanggan lebih banyak lagi. Hal ini dipicu juga dengan merebaknya virus Covid-19 saat ini, banyak pelaku usaha yang menderita dengan adanya batasan keluar rumah dan karantina masing-masing membuat pelanggan semakin terasing dan tidakberdaya.

Krisis yang sedang berlangsung menekan para pebisnis UMKM untuk terus bertahan. Ada sebagian bisnis yang justru meningkat, sedangkan yang lainnya berjuang untuk hanya satu atau dua penjualan. Ini berarti bahwa pelaku usaha harus memikirkan kembali upaya apa yang akan dilakukan agar membuat bisnis tetap berjalan, yang pada akhirnya aktifitas online bisa dijadikan strategi pemasaran tertentu untuk mendapatkan pelanggan.

Kelompok UMKM Kerajinan Tangan Rosela Asri merupakan salah satu UMKM dengan skala usaha mikro memiliki potensi untuk dikembangkan yang termasuk salah satu usaha yang berjuang untuk hanya satu atau dua penjualan. UMKM ini bergerak di bidang kerajinan tangan dari berbagai bahan diantaranya kain, goni, dan kulit sintetis yang berada di Kelurahan Pacar Kembang, Kecamatan Tambaksari Kota Surabaya. UMKM ini terdiri dari sekolompok ibu- ibu rumah tangga yang memproduksi beraneka ragam kerajinan tangan. Kerajinan tangan yang diproduksi antara lain kreasi flannel dan katun, daur ulang, box hantaran, tas, dan dompet.

\section{METODE PELAKSANAAN}

Metode pelaksanaan yang digunakan dalam kegiatan ini adalah metode pelatihan dan pendampingan. Metode pelatihan dilakukan dengan memberikan materi mengenai bagaimana menjadi pengusaha kerajinan yang mempunyai daya saing ditengah 
persaingan dan kondisi pandemi covid 19. Pemaparan yang diberikan berupa penyampaian materi yang berkaitan dengan pengadministrasian/pembukuan sederhana yang baik dan strategi pemasaran yang efektif. Pemaparan bertujuan agar peserta memiliki keterampilan pengelolaan keuangan dan pemasaran yang efektif dan efisien agar bisa meningkatkan kesejahteraan para pelaku bisnis di UMKM Rosela Asri Pacar Kembang Kecamatan Tambaksari Kota Surabaya. Pendampingan dilakukan setelah kegiatan pelatihan dengan memberikan contoh dan simulasi praktek pemasaran online dan administrasi keuangan /pembukuan keuangan sederhana.

\section{HASIL dan PEMBAHASAN}

Kelompok UMKM Kerajinan Tangan Rosela Asri merupakan salah satu UMKM dengan skala usaha mikro memiliki potensi untuk dikembangkan. UMKM ini bergerak di bidang kerajinan tangan dari berbagai bahan diantaranya kain, goni, dan kulit sintetis yang berada di Kelurahan Pacar Kembang, Kecamatan Tambaksari Kota Surabaya. UMKM ini terdiri dari sekolompok ibu- ibu rumah tangga yang memproduksi beraneka ragam kerajinan tangan. Kerajinan tangan yang diproduksi antara lain kreasi flannel dan katun, daur ulang, box hantaran, tas, dan dompet.

Sejak berdirinya UMKM Rosela Asri telah mampu menyerap tenaga kerja disekitarnya karena produknya adalah kerajinan tangan yang banyak dibutuhkan sebagai asesoris untuk pribadi, hantaran dan sovenir pernikahan. Pandemi covid 19 yang melanda dunia pada awal tahun 2020 berdampak pada keberlangsungan usaha UMKM Rosela Asri. Pelaksanaan kegiatan pelatihan pembekalan pada tgl 6 Agustus 2020 di kampus STIESIA Surabaya dan di lanjutkan dengan pendampingan secara berkala dan sesuai kebutuhan yaitu tentang administrasi keuangan/ pembukuan sederhana dan strategi pemasaran di UMKM Rosela Asri Kelurahan Pacar Kembang Kecamatan Tambaksari Kota Surabaya

Peraturan Menteri Kesehatan Republik Indonesia nomor 9 tahun 2020 tentang Pedoman Pembatasan Sosial Berskala Besar dalam rangka percepatan penanganan corona virus disease 2019 (covid-19) yang dikeluarkan pada 30 April 2020. yang berisi larangan kepada masyarakat untuk berkumpul atau mengadakan kegiatan yang berpotensi mengundang kerumunan massa. Bentuk tindakan pengumpulan massa yang dimaksud antara lain : pertemuan sosial, budaya, berdampak pula usaha kerajinan UMKM Rosela Asri yang secara bertahap mengalami penurunan permintaan dan penjualan produk kerajinannya utamanya untuk keperluan seminar dan pernikahan serta sebagai souvenir pribadi.

Namun Keputusan Menteri Kesehatan Republik Indonesia nomor: hk.01.07/menkes/328/2020 tentang Panduan Pencegahan dan Pengendalian Corona Virus Disease 2019 (covid-19) di tempat kerja perkantoran dan industri dalam mendukung keberlangsungan usaha pada situasi pandemi dan Keputusan Menteri Dalam Negeri nomor 440- 830 tahun 2020 tentang Pedoman Tatanan Normal Baru Produktif dan Aman Corona Virus Disease 2019 bagi aparatur sipil negara di lingkungan kementerian dalam negeri dan pemerintah daerah, bisa menjadi momentum bagi UMKM Rosela Asri untuk bangkit dalam kegiatan usahanya dengan mempersiapkan administrasi keuangan yang lebih baik dan strategi pemasaran yang lebih efektif guna menyongsong masa era new normal ini, agar permintaan dan penjualan hasil kerajinan meningkat

Seperti kita ketahui bersama bahwa pengelolaan/manajemen keuangan yang baik akan memudahkan sebuah bisnis manajemen dan menghindari bisnis dari risiko kebangkrutan. Mengacu pada Stoner (2009), manajemen keuangan adalah sekumpulan kegiatan dalam bentuk perencanaan dan pengambilan keputusan, mengatur, mengarahkan dan mengendalikan organisasi langsung tersebut sumber daya untuk mencapai tujuan organisasi tertentu secara efisien dan efektif. Pencatatan transaksi keuangan yang akurat 
dan tepat akan membantu UMKM untuk mempersiapkan strategi keuangan yang efektif.( Laily.et al. 2020)

Strategi pemasaran yang bisa dilakukan UMKM pasca Pandemi Covid-19 adalah OBAT, yang pelaksanaannya mudah, biaya murah dan bisa memantu UMKM bertahan (Sujatmika, 2020). Strategi pemasaran tersebut harus didukung oleh kemasan produk dan labeling yang menarik. OBAT adalah singkatan dari kata-kata Online, Berantai, Antar dan Teman. Strategi pemasaran Antar dan Teman dan berantai sudah dilakukan oleh ibu-ibu pelaku bisnis di UMKM Rosela Asri Kelurahan Pacar Kembang Kecamatan Tambaksari Kota Surabaya, namun strategi pemasaran online belum pernah dilakukan.

Walaupun usaha mikro di industri kerajinan, pengusaha cenderung mengukur kinerja mereka dengan kriteria lain dan menemukan kesuksesan, antara lain kepuasan pelanggan(Kompulla, R., dan Reijonen, H.,2007), namun perlu juga mempertimbangkan manfaat Pemasaran online adalah : mengurangi biaya; jangkauan luas; membangun hubungan dan mengubah prospek menjadi pelanggan (Sujatmiko,2020). Mengurangi biaya karena biaya yang dikeluarkan relatif lebih hemat jika dibanding dengan memasang iklan di media massa dan mencetak flyer dalam jumlah yang banyak. Jangkauan luas dalam menargetkan kegiatan promosi yang lebih luas daripada pemasaran yang dilakukan offline.

Masalah UMKM dapat diatasi sebagian besar melalui e-Commerce, dan ini akan memungkinkan mereka untuk bersaing dengan saingan bisnis mereka yang lebih besar(.Asadullah Khaskheli dan Yun Jun, 2016 ). Membangun hubungan dalam artian pemasaran online dapat memberi hubungan ke konsumen aatau pelanggan yang ada dengan konten yang menarik untuk remind tentang produk yang ditawarkan. Mengubah prospek menjadi pelanggan, maka pemasaran online adalah cara yang bagus utuk mengumpulkan prospek yaitu konsumen umum, yang memiliki kemungkinan tinggi, atau memiliki potensi tinggi untuk melakukan pembelian terhadap produk (barang dan jasa) yang ditawarkan, menjadi pelanggan.

Beberapa kendala mungkin saja muncul dalam e-commerce seperti yang diutarakan oleh Asghar Afshar Jahanshahi, et al.(2013), yaitu adnya kendala, seperti kegagalan koneksi internet, kesulitan menggunakan / menemukan situs web. dan kurangnya dukungan pengguna. Namun dengan perkembangan teknologi informasi yang semakin masif, maka kendala tersebut dapat diminimalisir.

Materi pelatihan dan pendampingan yangdiberikan adalah:

1. Pelatihan dan pendampingan administrasi keuangan yang baik dengan penyusunan pembukuan sederhana bagi ibu-ibu pelaku usaha UMKM Rosela Asri,

2. Pelatihan dan pendampingan dalam mengemas produk agar menjadi menarik dan memberikan teknik labelling agar mudah dikenal konsumen, dan

3. Pelatihan dan pendampingan pelaksanaan strategi pemasaran yang efektif untuk iklan, penjualan atau pencitraan merek produk UMKM, baik offline maupun berbasis web (online) melalui media sosial, facebook, whatsapp, dan instragram

Tabel 1 Daftar UMKM Rosela Asri Kelurahan Pacar Kembang Kecamatan Tambaksari Kota Surabaya

\begin{tabular}{clll}
\hline No & \multicolumn{1}{c}{ UMKM } & \multicolumn{1}{c}{ PRODUK } & \multicolumn{1}{c}{ NAMA PEMILIK } \\
1 & Zalsabillah Craft & Kreasi flanel dan katun & Ainur Rokhmah \\
2 & D \& Collection & $\begin{array}{l}\text { Box hantaran dan } \\
\text { Kreasi daur ulang goni }\end{array}$ & Haryana Indriasari \\
3 & Bertynalia & $\begin{array}{l}\text { Tas dan Dompet Souvenir } \\
\text { Kreatif daur ulang dan } \\
\text { Menjahit }\end{array}$ & $\begin{array}{l}\text { Bertynalia Puspita Ruus } \\
\text { Istinah }\end{array}$ \\
\hline
\end{tabular}


(Sumber : Data UMKM Rosela Asri)

Koordinasi materi pelatihan dan pendampingan yang berkelanjutan, di persiapkan dan dirancang oleh tim pengabdian masyarakat STIESIA secara bersama-sama.
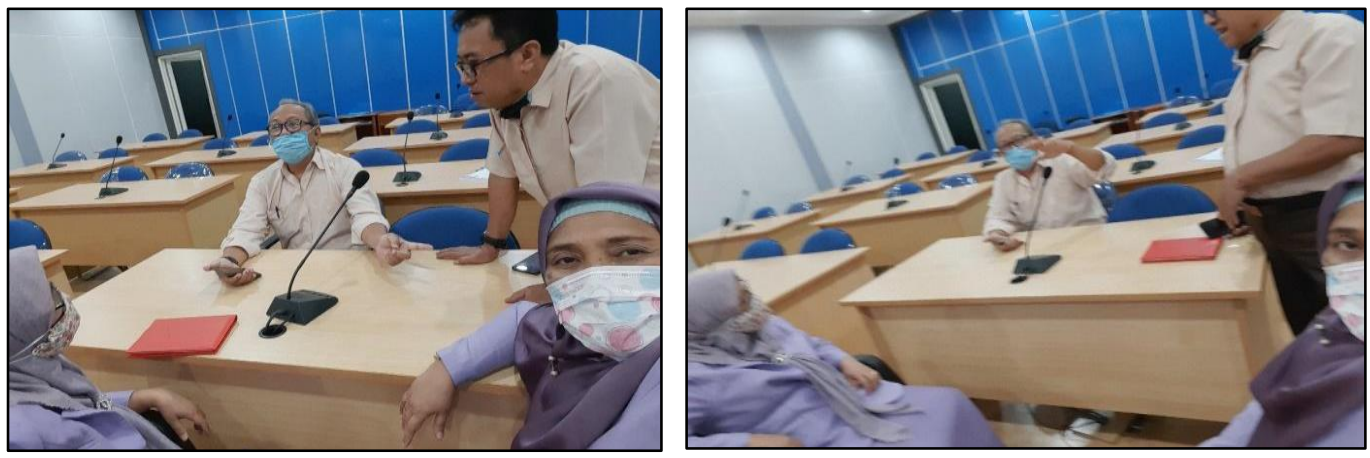

Gambar 1 Diskusi dan merancang program pelatihan dan pendampingan
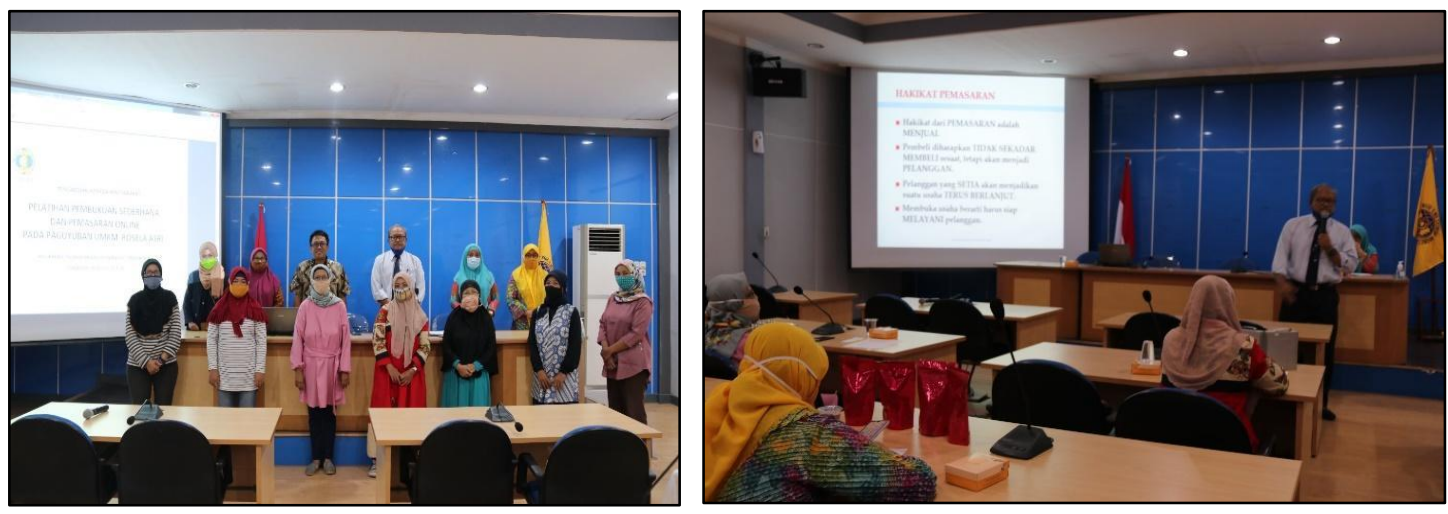

Gambar 2 Kegiatan penyampaian materi pelatihan

Produk yang dihasilkan oleh UMKM Rosela Asri Pacar Kembang Kecamatan Tambaksari Kota Surabaya , berupa kerajian, antara lain :

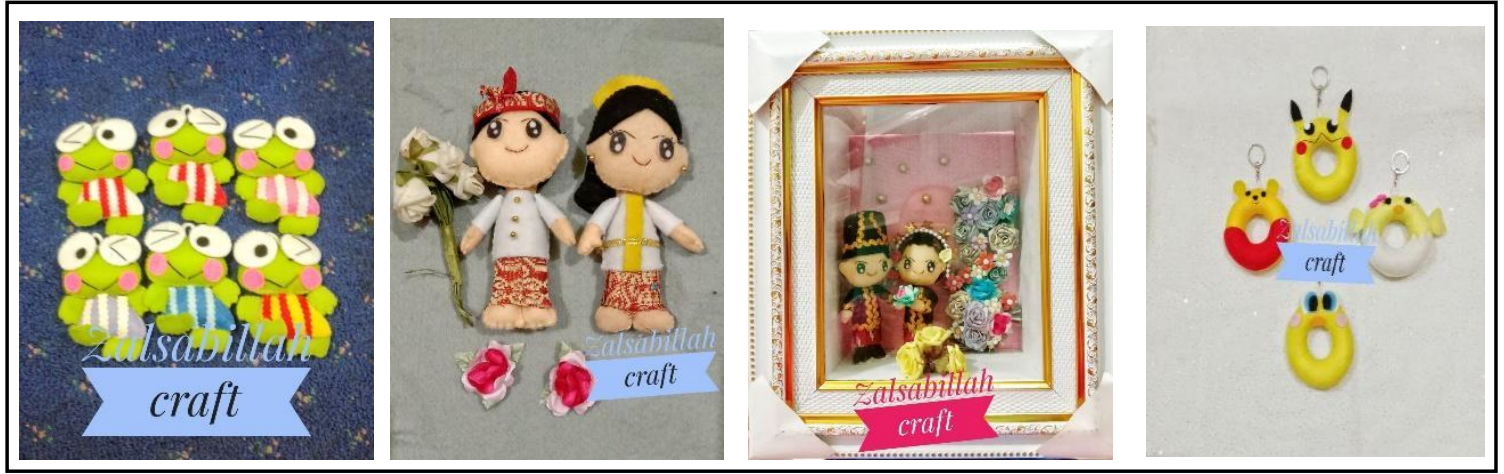




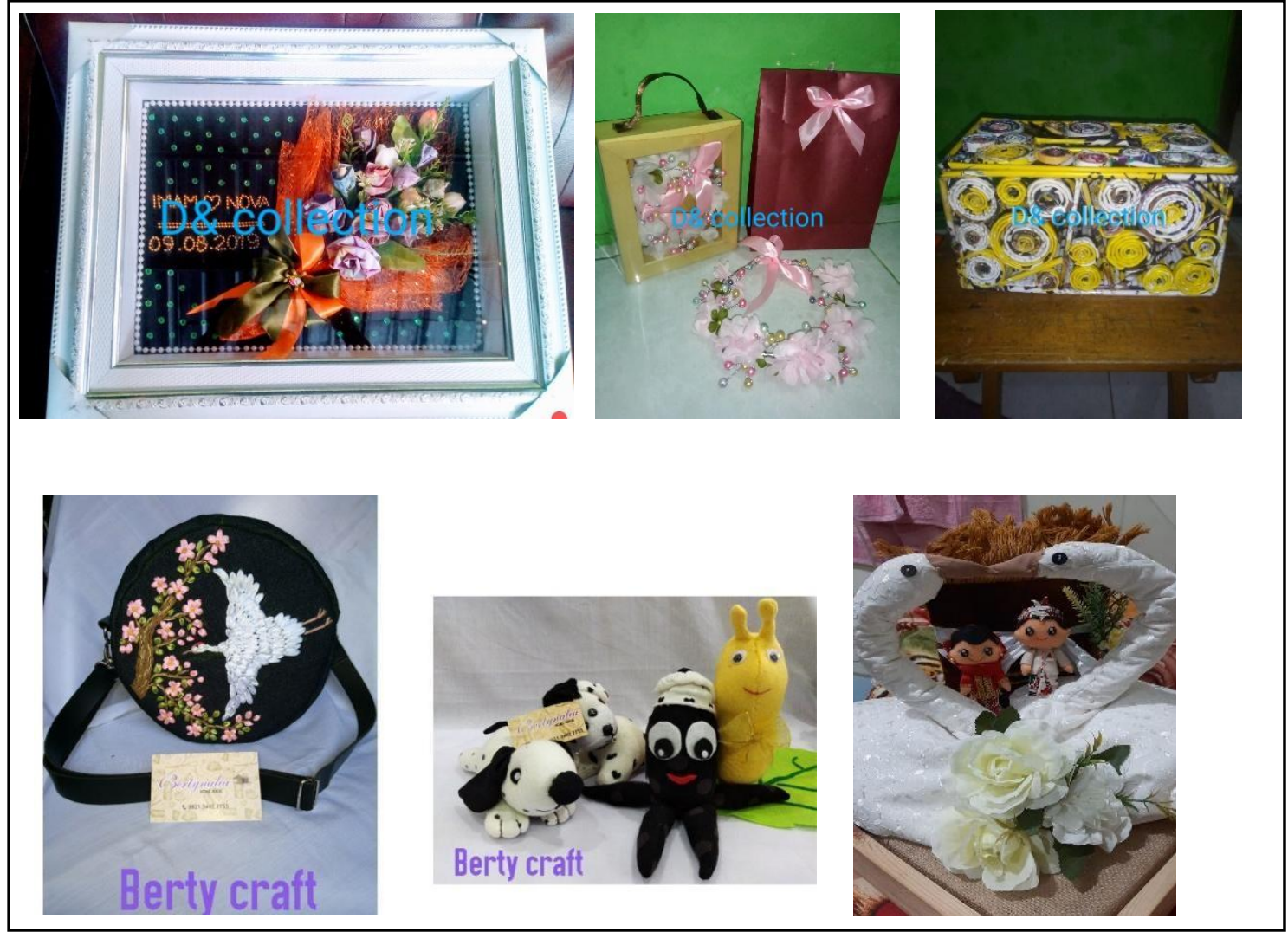

Gambar 3 Produk Kerajinan Tangan UMKM Rosela Asri

\section{KESIMPULAN}

Ibu-ibu/ pelaku bisnis yang tergabung pada UMKM Rosela Asri merasa senang dan termotivasi untuk bangkit dan bergairah kembali untuk mengelola bisnis/usahanya. Peserta banyak yang bertanya tentang pengelolaan keuangan dengan pembukuan sederhana yang benar, dan strategi pemasaran yang efektif antara lain : labelling, kemasan serta pemasaran online.

Namun yang menjadi catatan bagi pendamping adalah sebagian besar ibu-ibu/ pelaku bisnis di UMKM Rosela Asri belum memahami administrasi/pembukuan sederhana dan strategi pemasaran yang efektif, terutama dalam menghadapi persaingan terutama pada masa pandemi dan new normal ini. Ibu-ibu/ pelaku bisnis yang tergabung dalam UMKM Rosela Asri masih beranggapan bahwa usaha/bisnis yang dilakukan hanya untuk mengisi waktu luang, dan mengesampingan keuntungan / peningkatan kesejahetraan keluarga, sehingga tidak perlu pengelolaan yang efektif dan efisien Secara umum dapat dikatakan.

\section{UCAPAN TERIMA KASIH}

Terimakasih kepada Ketua Paguyuban UMKM Rosela Asri Kelurahan Pacar Kembang Kecamatan Tambaksari Kota Surabaya. yang telah memberikan kepercayaan pada TIM STIESIA Surabqaya untuk memberikan Pelatihan dan Pendampingan pada ibuibu / pelaku bisnis kerajinan pada UMKM Rosela Asri. Terimakasih juga disampaikan kepada Ketua STIESIA dan Kepala LP2M yang telah memberikan fasilitas sehingga kegiatan abdimas ini berjalan dengan lancar dan sukses 


\section{DAFTAR PUSTAKA}

Jahanshahi,A.A.,, Stephen X. Z, Alexander B. 2013. E-commerce for SMEs: empirical insights from three countries", Journal of Small Business and Enterprise Development, 20 (4): 849-865, https://doi.org/10.1108/JSBED-03-2012-0039

Keputusan Menteri Dalam Negeri nomor 440- 830 tahun 2020 tentang Pedoman Tatanan Normal Baru Produktif dan Aman Corona Virus Disease 2019 bagi aparatur sipil negara di lingkungan kementerian dalam negeri dan pemerintah daerah.

Keputusan Menteri Kesehatan Republik Indonesia Nomor : hk.01.07/menkes/328/2020 tentang Panduan Pencegahan dan Pengendalian Corona Virus Disease 2019 (covid-19) di tempat kerja perkantoran dan industri dalam mendukung keberlangsungan usaha pada situasi pandemi.

Khaskheli, A., dan Yun, J. (2016). A Review on the Importance of E-Commerce for SMEs in Pakistan. RISUS - Journal on Innovation and Sustainability 7(1): 11 - 17

Kompulla, R.,dan Reijonen, H.,(2007), Perception of Success and its Effect on Small Firm performance, Journal of Small Business and Enterprise Development, 14(4) : 689-701.

Laily.N., Triyonowati., Wahidahwati., N.F.Asyik., Sukaris.S. 2020.Innovative Behavior To The Success of Women Entrepreneurs Of Indonesian Batik.International Journal of Scientific \& Technology Research . 9 (6)

Peraturan Menteri Kesehatan Republik Indonesia nomor 9 tahun 2020 tentang Pedoman Pembatasan Sosial Berskala Besar dalam rangka percepatan penanganan corona virus disease 2019 (covid-19)

Pratiwi. 2012. Menyusun Laporan Keuangan Sederhana dengan Microsoft Excel. Media Ekonomi \& Teknologi Informasi. 19(1): 64- 70.

Stoner, J.A.F., 2009, Manajemen, Jakarta: Erlangga.

Sujatmika, 2020, Webinar UMKM UPN Jogyakarta,

Tjiptono,R. 2019. Strategi Pemasaran : Prisip dan Penerapan, Edisi 1., Andi Offset, Jogyakarta. 